\title{
Dealing with non-native species: what makes the difference in South America?
}

\author{
Karina L. Speziale · Sergio A. Lambertucci • \\ Martina Carrete · José L. Tella
}

\begin{abstract}
Non-native species have reached South American ecosystems and may be threatening the exceptional biodiversity of this region. However, people often value and exploit introduced species not knowing that they are non-natives, nor understanding their impacts. In this paper we analyze the trend of scientific research on introduced species in South America and whether a socio-cultural explanation could underlie the results by comparing them with European, North American and Australasian countries. We also controlled for research effort, which could reflect economic inequalities, by analyzing the articles published on introduced species in relation to the total number of articles published on related disciplines. Research trends suggest that non-native species are not of major concern for South American countries, there being less research on this topic in countries with
\end{abstract}

K. L. Speziale (\&) · S. A. Lambertucci

Ecotono Laboratory, Comahue National University,

Quintral 1250, 8400 Bariloche, Argentina

e-mail: karina.speziale@crub.uncoma.edu.ar;

karinaspeziale@gmail.com

M. Carrete

Department of Physical, Chemical and Natural Systems, University Pablo de Olavide, Ctra. Utrera km 1,

41013 Sevilla, Spain

\section{J. L. Tella}

Department of Conservation Biology, Estación Biológica de Doñana, EBD-CSIC, Avda. Américo Vespucio s/n, 41092 Sevilla, Spain higher biodiversity. Compared to other colonized countries such as the USA, New Zealand and Australia, research on non-native species was lagging and less abundant in South America, even when controlling for research effort. Historical and recent socio-cultural particularities may explain the similar attitudes and research input seen in South American countries and their Spanish and Portuguese colonizers. A generational amnesia, where younger generations descendent from European colonizers are not aware of past biological conditions, could be exacerbating this lack of concern. South American policies seem to reflect the low level of interest in non-native species shown by their citizens. National policies are poorly developed and mainly deal with alien species threatening productive systems. Given the strong cultural component of this dilemma, integrated ways to reverse this situation are needed, including education, international research collaboration, and a common South American policy.

Keywords Biodiversity - Biological invasions · Control · Culture · Introductions · Invasive species management

South America is one of the most biodiverse places on Earth and thus considered an invaluable world biodiversity hotspot (Myers et al. 2000). It is also a reservoir for countless medicines, biocides and food supplies, as 
well as being an extremely important area in the regulation of weather cycles (Mares 1986). Despite these facts, the introduction of non-native species, one of the major threats to the world's current biodiversity (Mack et al. 2000; Vilà et al. 2011), has been poorly studied or even not considered as a priority among governments in this region (DGPCB-SEAM and ALTERVIDA 2002; Matthews 2005; Coradin and Teixera Tortato 2006; Pyšek et al. 2008). This is particularly relevant when considering that at least 41 out of the 100 most invasive species in the world are already established in South America (IUCN-ISSG 2000).

Although ancient civilizations might be responsible for the first introductions of non-native species in South America (Tella 2011), most of them resulted from Post-Columbian biological exchanges during a period known as "Ecological imperialism” (Crosby 1986). Most of the species introduced intentionally or unintentionally in South America that became invasive are of European or Eurasian origin (Rapoport and Marino1998; IUCN-ISSG 2000; Speziale and Ezcurra 2011) reflecting the strong movements of biota occurring over centuries as a result of the diaspora of European people who settled in America as if it were their homeland (Pfeirffer and Voeks 2008; Simberloff and Rejmánek 2011).

In South America, as all over the world, non-native species may become a real threat to the ecosystems they invade (Mares 1986; Vitousek et al. 1996; Parker et al. 1999; Mack et al. 2000; Rodriguez 2001; Vilà et al. 2011). Although it must be considered that not every introduced species produces negative impacts to native biodiversity and that many of them can even provide economical and social benefits (Davis et al. 2011), it is important to be vigilant of introductions and to support management actions for non-native species that might alter native ecosystems (Simberloff et al. 2011).

While a few positive impacts of introduced species have been recorded in South America (Jaksic 1998; Novaro et al. 2000; Lambertucci et al. 2009), negative effects widely range from the extinction of endemisms and the emergence of infectious diseases to large-scale alterations of entire habitats (e.g., Rodriguez 2001; Jaksic 1998; Jaksic et al. 2002; Novillo and Ojeda 2008). The mongoose (Herpestes javanicus), introduced in northern South America to control rats and snakes on agricultural lands, quickly spread preying on endemic fauna and acting as a vector of rabies and leptospirosis (Ziller et al. 2005), while the giant African snail (Achatina fulica) transmitted eosinophilic meningitis in Brazil and Colombia (Ziller et al. 2005). Other introduced species act as ecosystem engineers, transforming and threatening complete ecosystems (Fig. 1), as well as changing their services such as beavers (Castor canadiensis), conifers and Eucalyptus sp. (Nosetto et al. 2005; Anderson et al. 2006; Quiroz et al. 2009; Simberloff et al. 2010). Even more profound, South America supports plantations of nim (Azadirachta indica), which has proved to be an aggressive invasive species for example in Ghana, where losses in agriculture and the environmental impacts have exceeded the benefits (Matthews 2005).

In addition to ecological impacts, economic issues must be considered. Losses from non-native species invasions imply millions of dollars spent by each country in control activities. Brazil loses US\$ 42,600,000 annually due to invasive species (Pimentel et al. 2001), and Argentina spends over US\$3,000,000 in programs to control introduced species (Ziller et al. 2005). However, these amounts are mainly to deal with threats to the productive system, not to protect biodiversity (Ministerio de Meio Ambiente e dos Recursos Naturais Renováveis 2006). In this sense, the US\$10,500,000 spent to eradicate invasive feral goats in the Galapagos Islands (Ecuador) stands out as an exception, since this and other cheaper programs were aimed at protecting the rich biodiversity of this archipelago (Carrion et al. 2011).

The number of introduced species studied in South America is still low compared to other regions, but conclusions cannot be drawn based upon published articles given their bias (Pyšek et al. 2008; Quiroz et al. 2009). Both the number of introduced species and their impacts are surely under-recorded given the low research effort devoted to non-native species in South American countries (Quiroz et al. 2009). Moreover, a further increase in the number of introduced species can be expected associated with the increase in gross domestic product (GDP) and trade in commodities in these developing countries (Pyšek et al. 2008; Hulme 2009). Despite differences in GDP among South American countries, they all show a growing trend ranging between 13 and 31\% growth in the last year (World Bank 2011). Additionally, there is increasing evidence indicating that a 


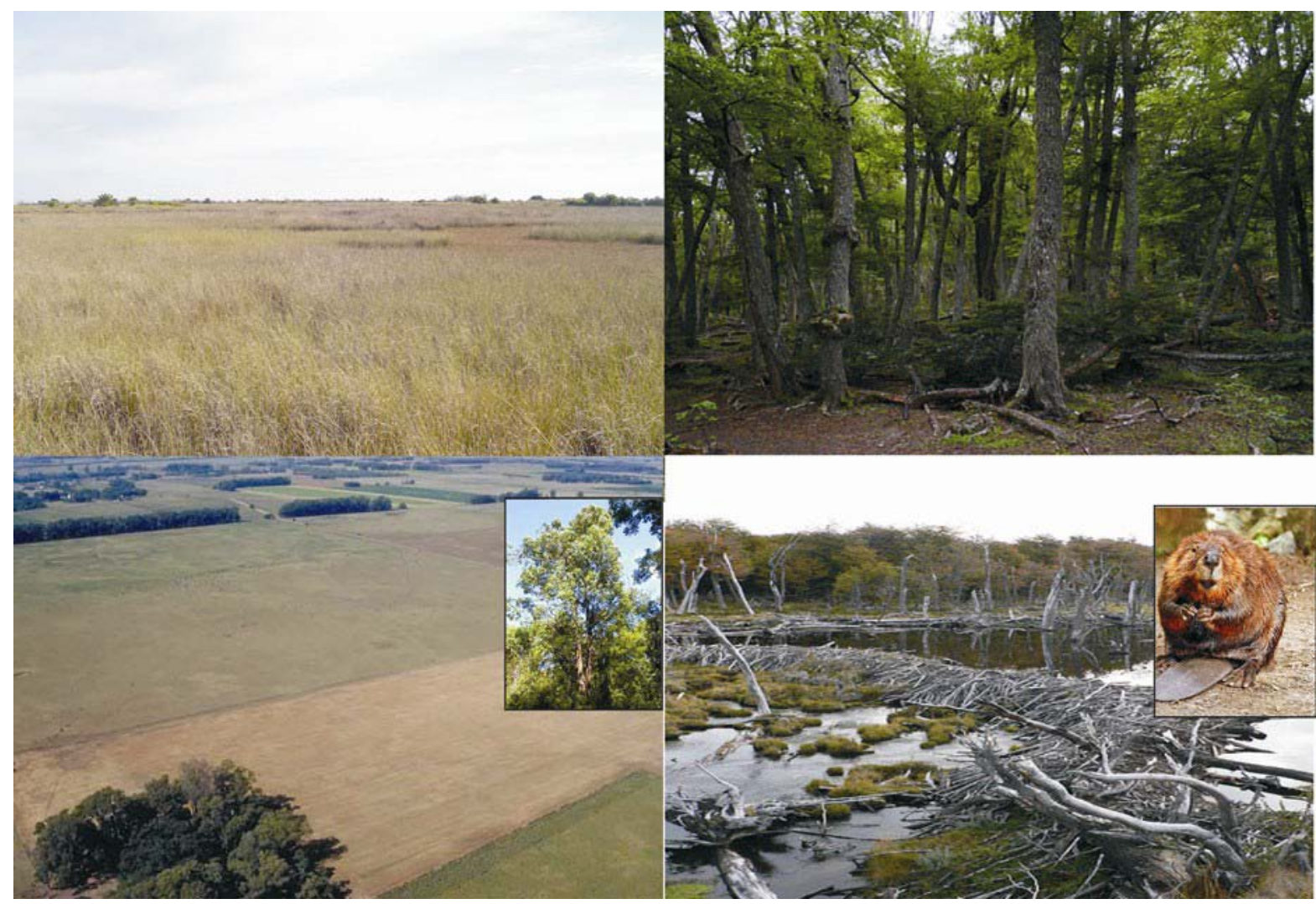

Fig. 1 Allogenic and autogenic non-native ecosystem engineers. Thousands of Eucalyptus sp. stands (bottom left) have transformed the ecosystem structure in thousands of square kilometers of La Pampa, Argentina, formerly dominated by

species rich areas are prone to host a higher richness of non-native species at large spatial scales (e.g. Lonsdale 1999; Fridley et al. 2007; Sax 2002; Speziale and Ezcurra 2011), and people tend to settle in rich areas facilitating the establishment of introduced species (Stohlgren et al. 2006). South America includes several areas with the highest species diversity in the world (Myers et al. 2000; Kier et al. 2005). In addition, its wide latitudinal gradient makes it a subcontinent of great biome diversity, with some biomes unique to this region due to its projection into high southern latitudes. Thus, we can predict that South America will possibly achieve the highest richness of nonnative species as well (Lonsdale 1999; Fridley et al. 2007; Speziale and Lambertucci 2010).

Throughout Europe, North America and most of Australasia, scientists are raising their voices and working to halt the negative consequences of introduced species, in clear contrast to those in South native grasslands (top left). Beavers (Castor canadensis, bottom right) are devastating native Nothofagus forests and modifying rivers in southern Chile and Argentina (top right)

America (Pyšek et al. 2008; Hulme 2009). The low scientific output on non-native species shown by South American countries could be related to both their degree of development and cultural idiosyncrasies (Pfeirffer and Voeks 2008; Simberloff 2006; Pyšek et al. 2008; Nuñez and Pauchard 2010). Although poor financial resources may explain the low research intensity (Pyšek et al. 2008), we believe that there is also a socio-cultural basis at work, and that the understanding of current and historic cultural particularities of each region could help to better deal with the negative impacts of non-native species. In this paper, we aim to elucidate the status of research on non-native species in South America and investigate the possibility of the existence of a historical-cultural base affecting the research history and intensity on introduced species in South America. In order to fulfill this aim we analyze the trend of scientific research on non-native species of South American countries, and 
compare it with South American Latin colonizers, such as Spain and Portugal, as well as with other Anglo-Saxon colony/colonizer countries such as Great Britain, USA, Australia and New Zealand. Particularly, we: (1) analyze the temporal trends of scientific research on non-native species in South America; (2) examine whether the research effort of each South American country could be influenced by its biodiversity; and (3) compare the research trends of South America with Spain, Portugal and Anglo-Saxon countries. We then relate these patterns to social attitudes and South American policies on non-native introduced species to finally provide further directions and recommendations.

Scientific productivity dealing with non-native species in South America

We used the Web of Science to search for articles on introduced species published between 1961 and 2010 (50 years), following the same criteria used by Simberloff and Von Holle (1999), and Nuñez and Pauchard (2010): “species AND (inva* OR introduced OR alien OR exotic OR non-native OR nonindigenous)", "the country" (for South America: Venezuela, Colombia, Brazil, Ecuador, Peru, Bolivia, Paraguay, Uruguay, Chile and Argentina; North America: USA; Europe: UK, Spain, and Portugal; and Australasia: Australia and New Zealand). We refined each search to only articles as Type of Publications, and by Subject Areas related to ecology, biodiversity conservation and agriculture. Any literature search can suffer from biases related to the databases or keywords used. Nonetheless, any source of bias would equally affect all countries and should not mask the general patterns in publication effort that we are comparing.

Our systematic search showed that research on introduced species is a rather new discipline in South America. Most South American countries began publishing on the topic during the 1990s and on average published 3.22 papers in that period. Countries such as Chile and Argentina started earlier (for example: Grigera and Rapoport 1983; Jaksic and Yañez 1983). During 2010, South American countries published between 4 and 87 articles each accumulating a total ranging from 40 to 676 per country since 1990. However, some differences between countries

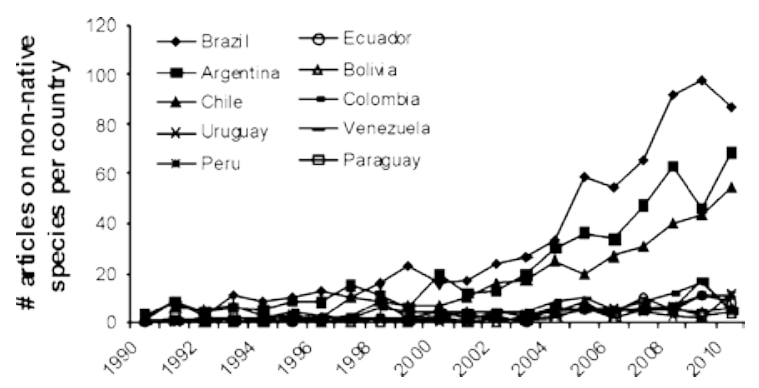

Fig. 2 Comparative research on non-native species in South America. Temporal patterns per country are shown as the absolute number of publications since 1990

are clear: while research effort on non-native species in Chile has grown in the last decade (see also Quiroz et al. 2009; Pauchard et al. 2010) just behind that of Brazil and Argentina, other countries maintain a very low level of research effort or may even show no increase in research effort (Fig. 2).

Scientific research may reflect the ideas and concerns of a society, but it is mainly constrained by available funds. The economic status of a region affects the research on introduced species as rich states invest more resources in their study than poor ones, but also because they have better developed science and education systems (Pyšek et al. 2008; Nuñez and Pauchard 2010). Poorer countries have fewer funds for research, and lowbudget national scientific agendas are prioritizing research in disciplines that contribute to the development and well-being of the country instead of ecological research (Nuñez and Pauchard 2010). The absolute research output on introduced species has been shown to be much lower in South America than in North America and Europe, which was reasonably attributed to differences in research funds among regions (Pyšek et al. 2008). To control for variance among countries in funds devoted to science in general as well as for different research disciplines, we also obtained from Web of Science the proportion of publications on non-native species from the total number of publications on ecology, biodiversity conservation and agricultural sciences for each country. This relative index should reflect the scientific interest in non-native species independent of funds available for the wider, related disciplines that embed most research on invasion biology. 


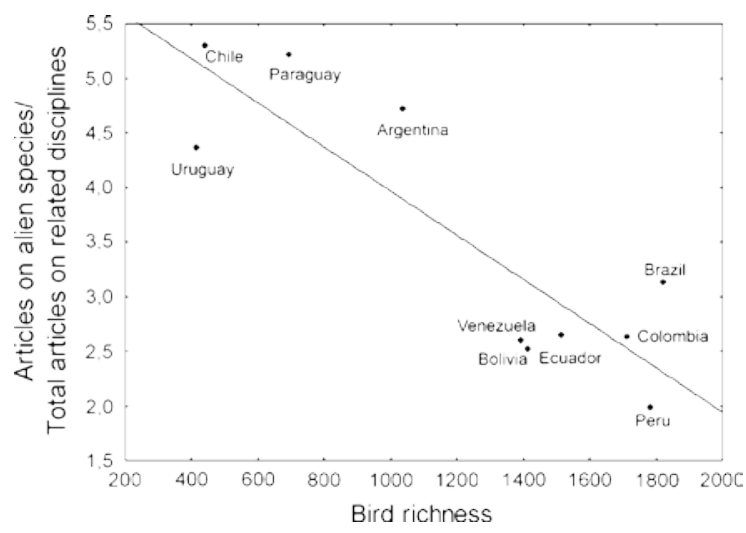

Fig. 3 Comparison of bird species richness per country and average index of publications on non-native species with respect to the total articles published on related disciplines since 1990 by each South American country. Line represents a linear regression $\left(R^{2}=0.76, P=0.001\right)$

Research effort on non-native species and biodiversity

Our results show that the most biodiverse countries in South America are those publishing the least on introduced species (Spearman correlation, rs $=$ $-0.87, \mathrm{P} \backslash 0.005$; Fig. 3). As the most biodiverse countries could be the most invaded areas (Lonsdale 1999), we investigated whether the differences in the intensity of non-native species research reflect differences among countries in their biodiversity and the interest in protecting it, controlling for economic inequalities. We analyzed the correlation between our relative index (percentage of publications on nonnative species with respect to the total number on related disciplines, averaged per country until 2010) and bird richness of each country. We consider this richness as a measure of biodiversity as it has proved to be a good surrogate of the latter and, because birds are one of the best known taxa, its values of richness are reliable (Norris and Pain 2002; Sergio et al. 2006).

Particularly, Bolivia, Peru, Ecuador, Colombia and Venezuela, which have the highest bird species richness, showed a low research output on non-native species as demonstrated by both their total number of articles published and their relative index of publications on introduced species. Contrasting cases are those of Brazil, Uruguay and Paraguay (Fig. 3). On the one hand, Brazil published more articles on non-native species since 1990 than any other South American country (676 in total; Fig. 1), but its publication index is low (2.64) given its high publication output in related disciplines as well $(25,598$ articles). On the other hand, Uruguay and Paraguay published just 45 and 40 articles on introduced species, respectively, since 1990, but their publication indexes are among the highest (4.37 and 5.22 respectively) due to their low publication output in related disciplines $(1,030$ and 766 respectively; Fig. 3). Argentina and Chile stand out by the fact that they showed both an increase in publication on non-native species that started a few years ago (total articles on non-native species $=464$ and 340, respectively) and a higher publication index (4.72 and 5.31, respectively) despite being among the countries with lower bird richness compared to northern South American countries (Fig. 3). This low research effort on non-native species in the most biodiverse countries would not be problematic if no invasion process were occurring; however, this is not the case (Ojasti 2001; Ziller et al. 2005; Quiroz et al. 2009) (Figs. 2, 3).

Historical perspective in contrast to an economic point of view

Similarly to South America, our systematic literature search showed that Spain and Portugal started publishing regularly on non-natives by the 1990s with an average of 3.3 papers in that period. In contrast, countries such as the USA and Australia started publishing regularly on non-natives by the 1980s and their average number of publications was 26.2 papers during the 1990s. In 2010, Spain and Portugal published 52 and 23 papers each while USA and Australia published 192 and 376 papers each. We then compared the relative index of publications on introduced species for South America with Spain, Portugal, Australasia (Australia and New Zealand), USA and UK. This relative index is lower for South America, Spain, and Portugal than for Australasia (Australia and New Zealand), USA and UK (Fig. 4). The pattern we found for non-South American countries has already been highlighted (Simberloff 2006). It has been suggested that the difference between the UK and the other European countries might be explained by the fact that islands are subject to higher impacts from alien species, whereas the higher interest of the USA, New Zealand and Australia might be explained by the short time elapsed since the first introductions, and by 
Fig. 4 Average proportion (1990-2010) of articles on non-native species with respect to the total scientific output in subjects related to ecology, biodiversity conservation and agriculture (multiplied by 100). Same letter indicates values that do not differ statistically (see details in "South American research effort in comparison with other countries")

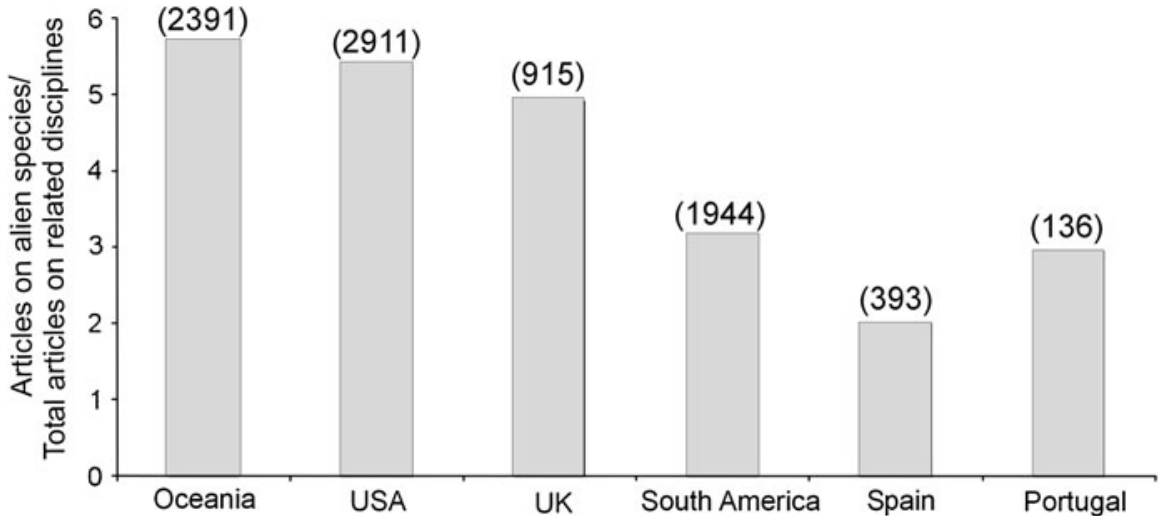

the Euroasiatic origin of the species introduced to these countries (Simberloff 2006). These explanations could help to understand our results for Spain and Portugal, which are continental countries that historically received non-native species. Attending to this line of reasoning, however, the research effort on introduced species of South America, being recently colonized and mainly receiving Euroasiatic species, should mirror that of the USA or Australasia rather than that of Spain and Portugal.

As shown by our results, the differences among countries in research effort on non-native species seem to be not just a matter of research budgets, nor differences between developed or developing countries, or differences due to their higher biodiversity and the interest in protecting it. Although this might be caused by an apparently lower number of introduced species, in South America compared to other regions, scientific information to properly assess this remains lacking. However, the impacts of the invasive species recorded to date are comparable to those in other regions of the globe (Quiroz et al. 2009; Pauchard et al. 2010); thus, a different explanation is needed. The low research effort on non-native species could be additionally reflecting a low level of interest shown by South American society. In fact, biological invasions are not yet seen as a major problem among South American citizenry or have only recently begun to be recognized as such (Ojasti 2001; Iriarte et al. 2005; Schüttler et al. 2011). Nor are they considered among current first-line conservation challenges by South American conservation biologists (Ojasti 2001; Ceballos et al. 2009). This may be creating a negative feedback in dealing with introduced species: the lower the level of research, the lower the detection of non- native species and their impacts, and therefore the less scientific and public interest in studying biological invasions.

Non-native species from a socio-cultural perspective

We wonder whether differences in research interest in non-native species between South America and countries such as the USA, Australia and New Zealand could reflect cultural particularities shared by their colonizers. We found differences in the rate of publications between different countries (ANCOVA comparing the relative index of the last 21 years for each country considering the year as a covariate: $\left.F_{(5,119)}=63.58 ; \mathrm{P} \backslash 0.001\right)$. Curiously, results showed that the former British colonies publish at a

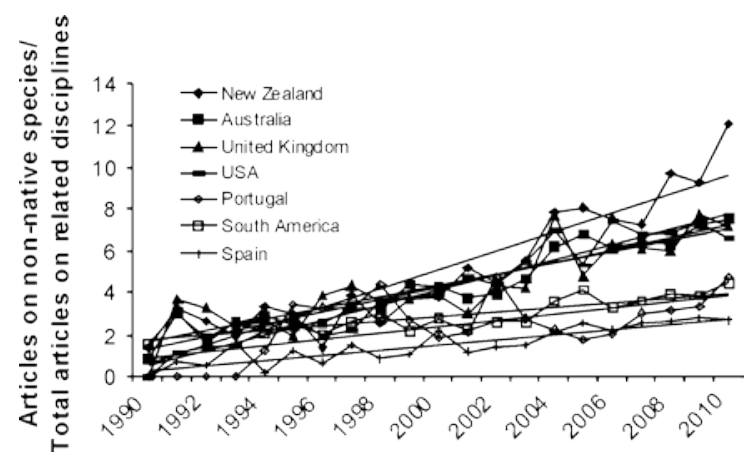

Fig. 5 Trend (1990-2010) of the proportion of articles on nonnative species with respect to the total scientific output in subjects related to ecology, biodiversity conservation and agriculture (multiplied by 100), comparing former European colonies and their respective colonizers. Countries names appear in the same order (from top to bottom) as in the figure 
similar rate to the United Kingdom, but different to South America, Spain and Portugal (Tukey post hoc test forming homogenous groups at a $\mathrm{P}=0.05$ ) considering their historical patterns (Fig. 5).

The motives that favored the introduction of nonnative species to South America were mostly the same as in New Zealand or the USA. However, in these countries introductions were already recognized as ecologically unsound by 1884 , and for example, New Zealand Acclimatization Societies changed their role from introducing species to preventing further introductions of non-native species after the Second World War (Simberloff and Rejmánek 2011). This could reflect an ancestral European burden coming from different colonizers, since while former British colonies (USA, New Zealand and Australia) are publishing at a similar rate to the UK, former South American colonizers (Spain and Portugal) are publishing at similar rate to South America (Figs. 4, 5). This cannot be explained by their lower income (Fazey et al. 2005), nor by difficulties in overcoming the barrier to publish in the English language (Clavero 2011), since research effort on introduced species was controlled for by the total research input in related disciplines that was published in international, English-language journals. Therefore, the comparatively low level of interest in the study of non-native species could reflect cultural traits or idiosyncrasies of the South American colonizers who did not react quickly when non-native species were recognized as a worldwide problem.

Both economic and social aspects are intimately involved when dealing with non-native species (Perrings et al. 2002). For example, results showed that the reaction of Spain to introduced species seems to be as slow and lagging as that in South American countries (Fig. 5). Indeed, it was not until the early 1990s, three decades after the publication of the seminal book by Elton (1958) on non-native species invasions, that both Spain and most South American countries started publishing more than one article per year on non-native species regularly. Most introductions of non-native species in Spain resulted from different initiatives for hunting, fishing or simply accidental escapes for which there were not regulation laws until very recently (Real decreto 1628/2011). In this sense, most of the more invasive species causing ecological impacts in Spain are today highly valued by people for game hunting, fishing, or commercial purposes (e.g., Clavero and García-Berthou 2006;
Acevedo et al. 2007; Tablado et al. 2010). This cultural and economic attachment to invasive species is detrimental for developing control and eradication actions (Pfeirffer and Voeks 2008) and is observed in South America as well (Lambertucci and Speziale 2011; Fig. 6). This might be related to the European origin of most introduced species reaching South America, together with the fact that in several countries most of the citizens are descendants of Europeans (Seldin et al. 2007), and that current generations were born after the introductions.

People in many parts of South America are not aware of the impacts of introduced species on native species, particularly when they were introduced long ago (Schüttler et al. 2011). For example, Southern Argentina and Chile are associated with non-native species such as pines (Pinus sp.), red deer (Cervus elaphus) and trout (e.g. Salmo trutta) (Fig. 6). Many national and international tourists admire these species in the mistaken belief that they are originally from the visited environment, to the detriment of native tree (e.g. Nothofagus sp.), deer (e.g. Hippocamelus bisulcus) or fish (e.g. Odontesthes hatcheri) species. Recent South American generations are far removed from the traditional knowledge of nature, thus making invasions "invisible" to them (Decocq 2010). Therefore, the case of South America might be considered as a shifting baseline in the form of generational amnesia, where knowledge extinction occurs because younger generations are not aware of past biological conditions (Papworth et al. 2009). Moreover, non-native species are often much valued and protected by local people, in part, because they represent an income (Pascual et al. 2009; Lambertucci and Speziale 2011). They are hunted or fished, restaurants advertise them as traditional dishes, and souvenir shops sell souvenirs with their likeness represented (Fig. 6).

Within indigenous communities the social memory of plant knowledge is dynamic and as non-native plant abundance increases they become part of the cultural reservoir (Ladio 2011). Moreover, non-native plants could be preferred over natives as they are more easily found given their cosmopolitan characteristics (Estomba et al. 2006; Ladio 2011). This could lead to two different outputs. On the one hand, the use of non-native species can produce the loss of traditional knowledge by replacement (Ladio and Lozada 2001; Ochoa et al. 2010). On the other hand, it can increase knowledge offering redundancy (Albuquerque and de Oliveira 2007). However, in the long run, both 


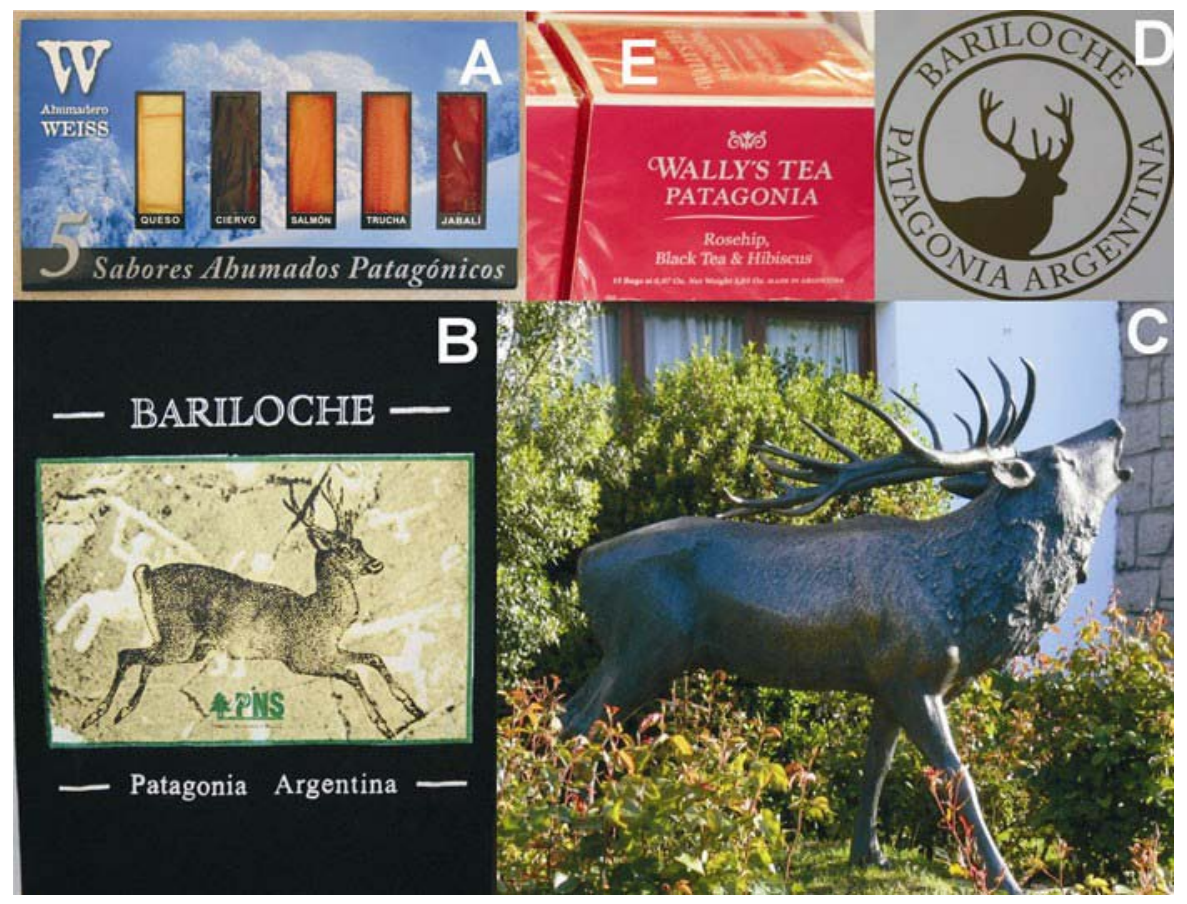

Fig. 6 a-d Non-native species used in different products sold at shops advertised as "typical from Patagonia”. a jabalí (wild boar Sus scrofa), trucha (trout Salvelinus sp), salmon (Salmo trutta), ciervo (red deer Cervus elaphus) and queso (cheese

outcomes could lead to the erosion of traditional knowledge due to the proliferative use of non-native species.

Societal interests and non-native species policies

South American policies seem to reflect the low level of social and research interest in non-native species shown by citizens. Almost a decade ago, the American countries agreed on the creation of an international committee to deal with global change. However, it did not explicitly work on introduced species and to date no group action has occurred. On the other hand, MERCOSUR, the common market for South America, stated through its resolution 10/94 the intention of its members to work together for the environment and sustainable development. Every South American country ratified the Convention on Biological Diversity supporting the proposal to prevent, control and eradicate alien species that pose a threat to local biodiversity and to create the made of cattle milk). b-d Red deer is advertised on a t-shirt (b) and on a sticker (d), and is represented in a statue at the entrance of the municipality of a Patagonian village in Argentina (c). d Rosehip (Rosa rubiginosa) tea necessary laws for resource protection. However, a basic starting point such as the generation of national reports on alien species has not been fulfilled or is incomplete, missing several invasive species, focusing only on some biomes or ecosystems, and mostly developing programs to address those species threatening productive systems rather than to protect biodiversity (Ziller et al. 2005). It is highly illustrative that the costly programs conducted to eradicate invasive species to protect the Galapagos Islands biodiversity were funded by international organizations and led by the Charles Darwin Foundation, while the major obstacles to successfully achieving these programs are posed by local authorities (Carrion et al. 2011).

In regards to national laws, the legislation of Brazil, Paraguay, Chile and Argentina deals with introduced species affecting fishing activities, such as the Argentinean law of 1998 on the ballast water change or the Brazilian law of 1967 to protect fishing. However, Argentina, Paraguay, Uruguay, Bolivia and Chile do not address non-native species 
in their national laws for the purpose of environmental protection (Argentina: Law No. 25 675, 2002; Paraguay: Law No. 816, 1996; Uruguay: Law No. 17 283, 2000; Bolivia: Law No.: 1 333, 1992; Chile: Law No. 19 300, 1994). According to the official websites of the national governments, only the national environmental protection laws of Brazil (Law Decree No. 4 339, 2002), Colombia (National Politic on Biodiversity Law No. 99, 1993), Peru (General Law on the Environment No. 28 611, 2005), and Venezuela (Organic Law on the Environment No. 5 833, 2006) refer to non-native species as problematic for the native biodiversity. However, most South American countries (except Uruguay, Venezuela, and Bolivia) have particular laws stating the need to fulfill an Environmental Impact Assessment if non-native species are to be introduced to these countries. These differences, as well as semantic issues when referring to introduced species, should be promptly addressed to improve legislation as well as to develop strategies and programs to protect native biodiversity from those non-native species that could cause its loss.

Furthermore, new routes of introduction now include the movement of species within the subcontinent and already five of the worst invasive species in the world that are native to South America, including the common water hyacinth Eichhornia crassipes, the sleeper weed Lantana camara, the Argentine ant Linepithema humile, the red imported fire ant Solenopsis invicta and the little fire ant Wasmannia auropunctata, are spreading among South American countries (IUCN-ISSG 2000). South American governments agree on the need for a common language and generic terms applicable to all introduced species and for rules on their treatment in different ecosystems and environmental situations (Ziller et al. 2005). They have also stated the need for effective and realistic diagnostic assessments and for technical resources and people trained in the detection, prevention and management of non-native species (Ojasti 2001). The bi-national treaty between Argentina and Chile to manage the invasion of the beaver (Castor canadensis) is a good example of international initiatives towards sound strategies to deal with problematic non-native species (Resolution $157 / 10-S A D S)$. Although more information is required as stated by most South American countries, this should not delay action.
Reducing differences among countries

South American countries show different species introductions, different policies and different budgets as well as different interests in dealing with non-native species. For example, despite the low average interest shown by most South American countries, Argentina and Chile stand out, particularly in the last few years during which they have increased both their raw number of publications on introduced species as well as their relative publication index. Some of these differences could be overcome with the help of IABIN (Inter-American Invasives Information Network). IABIN is leading Project I3 $\mathrm{N}$ to obtain and facilitate the exchange of information on non-native species in America. Within IABIN's framework, all countries are being financially and technically assisted in the cataloguing of their non-native species. Brazil and Chile have shown the most concern about this topic, reflected in their actions and policies. Brazil began the Conservation and Sustainable Use of Biological Brazilian Diversity Project in 2001, which aims to manage threatened species as well as to control invasive ones. In 2003, it concluded its first National report on introduced invasive species reporting 543 alien species, and by 2006 it created the Permanent Technical Chamber on Non-native Invasive Species (Coradin and Teixera Tortato 2006). Nonetheless, the principal projects being conducted in this country focus on the impact of alien species on agriculture. In Chile, the National Strategy for Biodiversity and the Action Plan for the Country were approved in 2005, resulting in the creation of the Operating Committee for Invasive Species Control (Molt 2006). Different actions followed, including workshops and a pilot project (Iriarte et al. 2005).

Among other countries, Paraguay published a report documenting 422 non-native species. However, the few projects conducted are intended to manage agricultural pests, not species affecting natural systems, so there remains a lack of research and citizen knowledge in respect to the impacts produced by nonpest introduced species (DGPCB-SEAM and ALTERVIDA 2002). Ecuador reported 750 non-native species for the whole country and a huge lack of knowledge regarding their impacts, with the exception of those occurring in the Galapagos Islands (see e.g. Carrion et al. 2011), which could be obscured by their economic returns (Alianza Jatun Sacha 2002; 
Guézou et al. 2010). Argentina conducted several workshops on non-native species in the late nineties, and by 2002 it began to organize the available information on introduced species. The first report included 372 non-native species (Zalba and Villamil 2003), although there are more species to be added to that list. Importantly, non-native species are still unconsidered as a priority by the Federal Environment Council in this country. Information for other countries is sparse and even less complete.

\section{Turning the tide}

So, how should South America deal with introduced species given the state of affairs on non-native species, the past and present history of introductions, the need for development, and the cultural attachment of citizens to non-native species? Surely, increased research, education, and the development of a common regional policy among South American countries (Speziale and Lambertucci 2010) would be first steps in the right direction.

Given the cultural dimension of biological invasions, strategies should begin by educating people on the value of native species and culture (Ojasti 2001). At the same time countries should support education on non-native species, not only on the positive impacts of some species but also on the problems that those introduced species that become invasive may pose to native ecosystems, culture and economy (Ojasti 2001; Pfeirffer and Voeks 2008). To date, the negative impacts of non-native species are not part of the curricula of South American schools (see for example: Diseño Curricular Básico para la escuela secundaria, Ministerio de Educación, Peru, 2004; Formar en ciencias: lo que hay que saber y saber hacer, Ministerio de Educación Nacional, Colombia, 2004). On the contrary, Uruguay teaches about the benefits of nonnative species plantations (Recursos naturales y paisajes agrarios, Programa para $3^{\circ}$ año bachillerato opción ciencias agrarias, Ministerio de Educación, Uruguay 2006). Given the fact that most teachers have not learned about the problems caused by some nonnative species, they can hardly be expected to teach about them. In this way, a non-virtuous circle closes and is very difficult to revert. Thus, the development of learning programs, within the formal education system as well as in the informal one, linking the introduction of species to human activities could help raise awareness about our responsibility in this process (Larson 2005). But education is also needed to change the cultural attachment of people, private and public institutions to some non-native species to the detriment of the native ones.

A shift in the vocabulary and discourse used to communicate information about introduced species would help reach people culturally attached to these species such as, for example, the diaspora for whom non-native species in the new environment represent their culture (Pfeirffer and Voeks 2008). The same ethos could favor both the introduction of non-native species as well as their eradication (Carruthers et al. 2011). For example, nationalism could favor the introduction of conifers for economic development, but could also support their eradication or control if they become invasive and negatively impact native ecosystems (Carruthers et al. 2011).

New policies and strategies are also needed to prevent new introductions, produce a common list of non-native species, maintain a constant evaluation of the status of introduced species, and support research on the current extent of invasions and the solutions to deal with them (Ojasti 2001; Young 2006). In this sense, international advice and collaborations with countries or centers making an outstanding scientific contribution to the problem should be sought. Preventive actions should avoid the movement of species between states, biogeographic regions or ecosystems, which is more important than the crossing of national borders (Young 2006; Paini et al. 2010). Black lists should focus on regional and national levels, and databases on introduced species, dates of introductions and management actions should be shared (Young 2006). The new policy should also rule on transport, tourism, pets, aquariums, garden species and seeds as the main current pathways of introductions (e.g., Carrete and Tella 2008; Hulme 2009; Walters et al. 2011). Without a common strategy throughout South America involving education, research, and policies, people will continue eating, wearing and valuing non-native species over native ones within the most biodiverse region of the world.

Acknowledgments This article benefited from discussions with F. Hiraldo. We appreciate the comments received from D. Vazquez, A. Pauchard, and two anonymous reviewers that helped to improve an earlier version of the manuscript. K.L.S. was funded by ANCPCYT-FONCYT (BID OC-AR 1728), and 
S.A.L. by CONICET- PIP 11420100100095. M.C. and J.L.T. benefited from funds to study biological invasions in Spain and South America by Repsol Foundation.

\section{References}

Acevedo P, Cassinello J, Hortal J, Gortázar C (2007) Invasive exotic aoudad (Ammotragus lervia) as a major threat to native Iberian ibex (Capra pyrenaica): a habitat suitability model approach. Divers Distrib 13:587-597

Albuquerque UP, de Olivera RF (2007) Is the use-impact of Caatinga species in Brazil reduced by the high species richness of medicinal plants? J Ethnopharmacol 113: 156-170

Alianza Jatun Sacha (2002) Proyecto de la red de información de especies invasivas del Ecuador continental e insular. IABIN

Anderson CB, Griffith CR, Rosemond AD, Rozzi R, Dollenz O (2006) The effects of invasive North American beavers on riparian plant communities in Cape Horn, Chile. Do exotic beavers engineer differently in sub-Antarctic ecosystems? Biol Conserv 128:467-474

Carrete M, Tella JL (2008) Wild-bird trade and exotic invasions: a new link of conservation concern? Front Ecol Environ 6:207-211

Carrion V, Donlan CJ, Campbell KJ, Lavoie C, Cruz F (2011) Archipelago-wide island restoration in the Galápagos Islands: reducing costs of invasive mammal eradication programs and reinvasion risk. PLoS ONE 6(5):e18835. doi: 10.1371/journal.pone.0018835

Carruthers J, Robin L, Hattingh JP, Kull CA, Rangan H, van Wilgen BW (2011) A native at home and abroad: the history, politics, ethics and aesthetics of acacias. Divers Distrib 17:810-821

Ceballos G, Vale MM, Bonacic C, Calvo-Alvarado J, List R, Bynum N, Medellín RA, Simonetti JA, Rodríguez JP (2009) Conservation challenges for the austral and neotropical America section. Conserv Biol 23:811-817

Clavero M (2011) Language bias in ecological journals. Front Ecol Environ 9:93-94

Clavero M, García-Berthou E (2006) Homogenization dynamics and introduction routes of invasive freshwater fish in the Iberian Peninsula. Ecol Appl 16:2313-2324

Coradin L, Teixera Tortato D (2006) Espécies exóticas invasoras: situação Brasileira. Ministério do Meio Ambiente, Secretaria de Biodiversidade e Florestas, Brasília

Crosby AW (1986) Ecological imperialism. The biological expansion of Europe, 900-1900. Cambridge University Press, Cambridge

Davis M et al (2011) Don’t judge species on their origin. Nature 474:153-154

Decocq G (2010) Invisibility promotes invasibility. Front Ecol Environ 8:346-347

DGPCB-SEAM, ALTERVIDA (2002) Proyecto de información sobre especies exóticas invasoras I3 N-Paraguay. IABIN. Viewed 24, January 2011

Elton CS (1958) The ecology of invasions by animals and plants. University of Chicago Press, Chicago
Estomba E, Ladio A, Lozada M (2006) Medicinal wild plant knowledge and gathering patterns in a Mapuche community from North-western Patagonia. J Ethnopharmacol 103:109-119

Fazey I, Fischer J, Lindenmayer DB (2005) Who does all the research in conservation biology? Biodivers Conserv 14:917-934

Fridley JD, Stachowicz JJ, Naeem S, Sax DF, Seabloom EW, Smith MD, Stohlgren TJ, Tilman D, Von Holle B (2007) The invasion paradox: reconciling pattern and process in species invasions. Ecology 88:3-17

Grigera DE, Rapoport EH (1983) Status and distribution of the European hare in South America. J Mammal 64:163-166

Guézou A, Trueman M, Buddenhagen CE, Chamorro S, Guerrero AM, Pozo P, Atkinson R (2010) An extensive alien plant inventory from the inhabited areas of Galápagos. PLOS ONE 5:1-8

Hulme PE (2009) Trade, transport and trouble: managing invasive species pathways in an era of globalization. J Appl Ecol 46:10-18

Iriarte JA, Lobos GA, Jaksic FM (2005) Invasive vertebrate species in Chile and their control and monitoring by governmental agencies. Rev Chil Hist Nat 78:143-154

IUCN-ISSG (2000) 100 of the world's worst alien invasive species. http://www.issg.org/database/species/search.asp? $\mathrm{st}=100$ ss. Viewed 24, January 2011

Jaksic FM (1998) Vertebrate invaders and their ecological impact in Chile. Biodivers Conserv 7:1427-1445

Jaksic FM, Yañez JL (1983) Rabbit and fox introductions in Tierra del Fuego: history and assessment of the attempts at biological control of the rabbit infestation. Biol Conserv 26:367-374

Jaksic MF, Iriarte JA, Jiménez JE, Martínez DR (2002) Invaders without frontiers: cross-border invasions of exotic mammals. Biol Invasions 4:157-173

Kier G, Mutke J, Dinerstein E, Ricketts TH, Küper W, Kreft H, Barthlott W (2005) Global patterns of plant diversity and floristic knowledge. J Biogeogr 32:1107-1116

Ladio AH (2011) Traditional knowledge of edible wild native and exotic plants in the context of cultural change in human populations of arid Patagonia. Biorem Biodiv Bioavail 5:60-64

Ladio AH, Lozada M (2001) Nontimber forest product use in two human populations from northewest Patagonia: a quantitative approach. Human Ecol 29:367-380

Lambertucci SA, Speziale KL (2011) Protecting invaders for profit. Science 332:35

Lambertucci SA, Trejo A, Di Martino S, Sánchez-Zapata JA, Donázar JA, Hiraldo F (2009) Spatial and temporal patterns in the diet of the Andean Condor: ecological replacement of native fauna by exotic species. Anim Conserv 12:338-345

Larson BMH (2005) The war of the roses: demilitarizing invasion biology. Front Ecol Environ 3:495-500

Lonsdale WM (1999) Global patterns of plant invasions and the concept of invasibility. Ecology 80:1522-1536

Mack RN, Simberloff D, Lonsdale WM, Evans H, Clout M, Bazzaz FA (2000) Biotic invasions: causes, epidemiology, global consequences, and control. Ecol Appl 10:689-710

Mares MA (1986) Conservation in South America: problems, consequences, and solutions. Science 233:734-739 
Matthews S (2005) South America invaded: the growing danger of invasive alien species. GISP-Global Invasive Species Program, Nairobi

Ministerio de Meio Ambiente e dos Recursos Naturais Renováveis (2006) Espécies exóticas invasoras: situação Brasileira. Ministerio do Meio Ambiente, Secretaria de Biodiversidade e Florestas, Brasília, Brazil

Molt KG (2006) Reporte de actividades, Red de Especies Invasoras I3 $\mathrm{N}$-Chile. CONAMA

Myers N, Mittermeier RA, Mittermeier CG, da Fonseca GAB, Kent J (2000) Biodiversity hotspots for conservation priorities. Nature 403:853-858

Norris K, Pain DJ (2002) Conserving bird biodiversity: general principles and their application. Cambridge University Press, Cambridge

Nosetto MD, Jobbágy EG, Paruelo JM (2005) Land-use change and water losses: the case of grassland afforestation across a soil textural gradient in central Argentina. Glob Change Biol 11:1101-1117

Novaro AJ, Funes MC, Walker RS (2000) Ecological extinction of native prey of a carnivore assemblage in Argentine Patagonia. Biol Conserv 92:25-33

Novillo A, Ojeda RA (2008) The exotic mammals of Argentina. Biol Invasions 10:1333-1344

Nuñez MA, Pauchard A (2010) Biological invasions in developing and developed countries: does one model fit all? Biol Invasions 12:707-714

Ochoa JJ, Ladio AH, Lozada M (2010) Uso de recursos herbolarios entre mapuches y criollos de la comunidad campesina de Arroyo Las Minas (Río Negro, Patagonia Argentina). Boletín Latinoamericano y del Caribe de Plantas Medicinales y Aromáticas 9:269-276

Ojasti J (2001) Estrategia regional de biodiversidad para los países del trópico andino. Convenio de cooperación técnica no reembolsable ATN/JF-5887-RG CAN-BID, Caracas

Paini DR, Worner SP, Cook DC, De Barro PJ, Thomas MB (2010) Threat of invasive pests from within national borders. Nat Commun 1:115

Papworth SK, Rist J, Coad L, Milner-Gulland EJ (2009) Evidence for shifting baseline syndrome in conservation. Conserv Lett 2:93-100

Parker IM, Simberloff D, Lonsdale WM, Goodell K, Wonham M, Kareiva PM, Williamson MH, Von Holle B, Moyle PB, Byers JE, Goldwasser L (1999) Impact: toward a framework for understanding the ecological effects of invaders. Biol Invasions 1:3-19

Pascual MA, Lancelotti JL, Ernst B, Ciancio JE, Aedo E, García-Asorey M (2009) Scale, connectivity, and incentives in the introduction and management of non-native species: the case of exotic salmonids in Patagonia. Front Ecol Environ 7:533-540

Pauchard A, Quiroz C, García RA, Anderson CB, Arroyo MTK (2010) Invasiones biológicas en América Latina y el Caribe (LAC): Tendencias en la investigación para la conservación. In: Simonetti JA, Dirzo R (eds) Conservación biológica: Perspectivas desde América Latina. Editorial Universitaria, Santiago, pp 79-90

Perrings C, Williamson M, Barbier EB, Delfino D, Dalmazzone S, Shogren J, Simmons P, Watkinson A (2002) Biological invasion risks and the public good: an economic perspective. Conserv Ecol 6:1-7
Pfeirffer JM, Voeks RA (2008) Biological invasions and biocultural diversity: linking ecological and cultural systems. Environ Conserv 35:281-293

Pimentel D, McNair S, Janecka J, Wightman J, Simmonds C, O’Connell C, Wong E, Russel L, Zern J, Aquino T, Tsomondo T (2001) Economic and environmental threats of alien plant, animal, and microbe invasions. Agr Ecosyst Environ 84:1-20

Pyšek P, Richardson DM, Pergl J, Jarošík V, Sixtová Z, Weber E (2008) Geographical and taxonomic biases in invasion ecology. Trends Ecol Evol 23:237-244

Quiroz C, Pauchard A, Cavieres LA, Anderson CB (2009) Análisis cuantitativo de la investigación en invasiones biológicas en Chile: tendencias y desafíos. Rev Chil Hist Nat 82:497-505

Rapoport EH, Marino CR (1998) Patterns of commerce and the dispersal of weeds. In: Gopal B, Pathak PS, Saxena KG (eds) Ecology today: an anthology of contemporary ecological research. International Scientific Publications, New Delhi

Rodriguez JP (2001) Exotic species introductions into South America: an underestimated threat? Biodivers Conserv 10:1983-1996

Sax DF (2002) Native and naturalized plant diversity are positively correlated in scrub communities of California and Chile. Divers Distrib 8:193-210

Schüttler E, Rozzi R, Jax K (2011) Towards a societal discourse on invasive species management: a case study of public perceptions of mink and beavers in Cape Horn. J Nat Cons 19:175-184

Seldin MF, Tian C, Shigeta R, Scherbarth HR, Silva G, Belmont JW, Kittles R, Gamron S, Allevi A, Palatnik SA, Alvarellos A, Paira S, Caprarulo C, Guillerón C, Catoggio LJ, Prigione C, Berbotto GA, García MA, Perandones CE, Pons-Estel BA, Alarcon-Riquelme ME (2007) Argentine population genetic structure: large variance in Amerindian contribution. Am J Phys Anthropol 132:455-462

Sergio F, Newton I, Marchesi L, Pedrini P (2006) Ecologically justified charisma: preservation of top predators delivers biodiversity conservation. J Appl Ecol 43:1049-1055

Simberloff D (2006) Preface. In: Pascual M, Lorvelec O, Vigne JD (eds) 11, 000 ans d’historie des vertébrés en France. Quæ, Paris

Simberloff D, Rejmánek M (2011) Encyclopedia of biological invasions. University of California Press, Berkeley

Simberloff D, Von Holle B (1999) Positive interactions of nonindigenous species: invasional meltdown? Biol Invasions 1:21-32

Simberloff D, Nuñez MA, Ledgard NJ, Pauchard A, Richardson DM, Sarasola M, Van Wilgen B, Zalba SM, Zenni RD, Bustamante R, Peña E, Ziller S (2010) Spread and impact of introduced conifers in South America: Lessons from other southern hemisphere regions. Austral Ecol 35: 489-504

Simberloff D et al (2011) Non-native species: 141 scientists object. Nature 475:36

Speziale KL, Ezcurra C (2011) Patterns of alien plant invasions in northwestern Patagonia, Argentina. J Arid Environ 75: 890-897

Speziale K, Lambertucci S (2010) A call for action to curb invasive species in South America. Nature 467:153 
Stohlgren TJ, Barnett D, Flather C, Fuller P, Peterjohn B, Kartesz J, Master LL (2006) Species richness and patterns of invasion in plants, birds, and fishes in the United States. Biol Invasions 8:427-447

Tablado Z, Tella JL, Sánchez-Zapata JA, Hiraldo F (2010) The paradox of the long-term positive effects of a North American crayfish on a European community of predators. Conserv Biol 24:1230-1238

Tella JL (2011) The unknown extent of ancient bird introductions. Ardeola 58(2):399-404

Vilà M, Espinar JL, Hejda M, Hulme PE, Jarošík V, Maron JL, Pergl J, Schaffner U, Sun Y, Pyšek P (2011) Ecological impacts of invasive alien plants: a meta-analysis of their effects on species, communities and ecosystems. Ecol Lett 14:702-708

Vitousek PM, D’Antonio CM, Loope LL, Westbrooks R (1996) Biological invasions as global environmental change. Am Sci 84:218-228
Walters L, Odom R, Zaleski S (2011) The aquarium hobby industry and invasive species: has anything changed? Front Ecol Environ 9:206-207

World Bank (2011) http://data.worldbank.org/indicator/NY. GDP.MKTP.CD. Accessed October 4th, 2011

Young TR (2006) National and regional legislation for promotion and support to the prevention, control and eradication of invasive species. Environment Papers, The World Bank, Washington

Zalba SM, Villamil CB (2003) Proyecto: Red de información sobre especies exóticas invasoras- $\mathrm{I} 3 \mathrm{~N}$ - Argentina. IABIN

Ziller SR, Reaser JK, Neville LE, Brandt K (2005) Invasive alien species in South America: national reports and directory of resources. Global Invasive Species Programme, Cape Town 